\title{
МЕТОДИКА РОЗРАХУНКУ ЕФЕКТИВНОСТІ ЕКСПЛУАТАЦІЇ ВАНТАЖНИХ АВТОМОБІЛІВ
}

\begin{abstract}
У роботі розглядається питання оцінки ефективності експлуатації вантажних автомобілів. Встановлено, що ефективність експлуатації автомобілів функціонально пов'язана з економічною ефективністю, надійністю і безвідмовністю автомобілів - зв'язок між якими представлено у вигляді структурно-функціональної схеми.

3'ясовано, що чистий прибуток автотранспортного підприємства залежить від трьох складових: тарифної вартості перевезень, собівартості перевезень і величини податків.

Наведені формули для визначення собівартості перевезень вантажів, витрат на транспортування вантажу, умовно-технічних витрат. В структурі умовно-технічних витрат розглянуті витрати: на паливо, на мастильні матеріали, на шини, на запасні частини і матеріали при виконанні технічного обслуговування $\mathrm{i}$ ремонту рухомого складу.

На основі аналізу структури собівартості перевезень вантажів автомобілями встановлено десять показників, якими визначаються «незаплановані» витрати, такі наприклад, як: витрати, пов'язані зі збільшенням відстані транспортування вантажу; витрати, пов'язані з ушкодженням і втратою вантажу; витрати, пов'язані з додатковим зберіганням вантажу; витрати, пов'язані зі збільшенням вартості підготовки вантажу до перевезення; витрати, пов'язані зі збільшенням вартості складування вантажу.

Встановлено, що умовно-постійні витрати (витрати на амортизацію, накладні витрати, величина податків) не впливають істотно на величину річного економічного ефекту при оновленні рухомого парку.

Отримані залежності для визначення: питомих умовно-технічних витрат на експлуатацію автомобіля при доставці вантажів; величини річного економічного ефекту, що досягається власником вантажних автомобілів при оновленні рухомого складу.

Ключові слова: вантажний автомобіль, критерій, рухомий склад, собівартість, умовно-організаційні витрати, умовно-технічні витрати.
\end{abstract}

\section{ВСТУП}

Оцінка ефективності експлуатації вантажних автомобілів здійснюється на основі розрахунків сукупності показників і складових, якими визначаються витрати на рухомий склад (РC) і величини доходу, який отримує автотранспортне підприємство (АТП) від перевезення вантажів. При цьому АТП не завжди отримує прибуток від своєї діяльності, такий стан справ зумовлений двома взаємопов'язаними причинами - низьким використання наявного РС i високими поточними витратами АТП, включаючи експлуатаційні витрати. А тому, з'ясування методики розрахунків основних показників, якими характеризується ефективність експлуатації вантажних автомобілів $\epsilon$ важливим для діяльності АТП, які прагнуть зменшити поточні витрати і збільшити величину чистого прибутку.

\section{АНАЛІЗ ЛІТЕРАТУРНИХ ДАНИХ ТА ПОСТАНОВКА ПРОБЛЕМИ}

Проблемі підвищення ефективності експлуатації вантажних автомобілів приділяється значна увага науковців, зокрема дану проблему досліджують: Боричов С.М., Бочкарьова М.М., Гудков В.О., Захаров М.С., Мигачов В.А., Паулі М.В., Пеньшин М.В., Резник Л.Г., Фасхієв А.Х. Дослідження даної проблематики здійснюється у напрямках визначення витрат на технічний стан та експлуатацію вантажних автомобілів [1-5], удосконалення системи технічного обслуговування і ремонту РС [6], удосконалення процесів прийняття управлінських рішень [7].

Прагнення автоперевізників оновлювати РС є цілком виправданим в умовах конкуренції, при цьому для АТП актуальним питанням є оцінка ефективності експлуатації наявних вантажних автомобілів і прийняття рішення щодо оновлення. Оскільки не завжди утримання вартісних вантажівок в АТП гарантує високі прибутки з перевезень, надійність таких автомобілів висока, але також високі експлуатаційні витрати (наприклад вартість запасних частин, мастильних матеріалів і т.д.).

Методики розрахунку ефективності експлуатації вантажних автомобілів являють собою певний алгоритм громіздких математичних обчислень сукупності показників, якими характеризуються витрати і дохідні статті діяльності АТП.

Одна із методик розрахунку ефективності експлуатації вантажних автомобілів представлена в роботі Мигачова В.А. [8], який зосередив особливу увагу на визначенні експлуатаційних витрат. 
Зважаючи на те, що методика розрахунку ефективності експлуатації вантажних автомобілів досить детально обгрунтована науковцем, але для іiі застосування необхідно здійснити грунтовний аналіз, а тому постає необхідність у додатковому дослідженні складових методики.

\section{ЦІЛЬ ТА ЗАДАЧІ ДОСЛІДЖЕННЯ}

Основна мета дослідження - розглянути показники, якими характеризується ефективність експлуатації вантажних автомобілів, з'ясувати формули для їх визначення. Система таких показників визначає зміст методики розрахунку ефективності експлуатації вантажних автомобілів.

\section{РЕЗУЛЬТАТИ ДОСЛІДЖЕНЬ}

При визначенні ефективності парку вантажних автомобілів необхідно відрізняти економічну ефективність експлуатації і загальніше поняття ефективності, що включає не лише економічні, але і соціальні, екологічні аспекти, пов'язані з експлуатацією автомобілів [5]. Нині ефективність експлуатації автомобілів функціонально пов'язана 3 економічною ефективністю, надійністю і безвідмовністю автомобілів (рис. 1) [7].

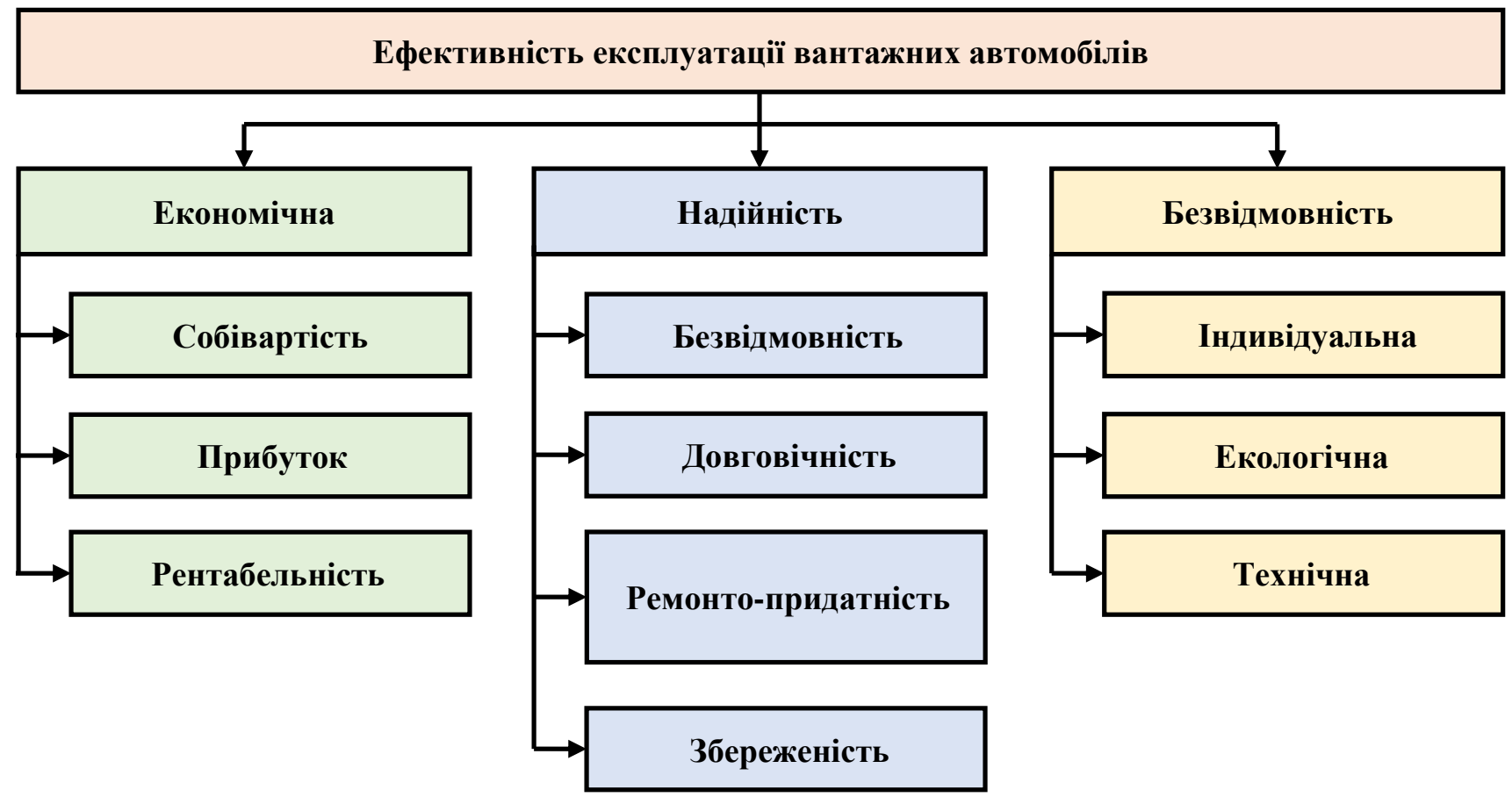

Рисунок 1 - Структурно-функціональна схема зв'язків при розгляді ефективності експлуатації вантажних автомобілів [8, с. 51]

Підвищення прибутку РС можливо в наслідок зміни (підвищення) продуктивності парку, зміни (зниження) витрат на транспортування вантажу. При цьому підвищується вантажообіг і (або) зменшується собівартість перевезень, що призводить до зростання економічного ефекту (зрештою і прибутку) у власника парку рухомого складу.

Загальна залежність чистого прибутку АТП має вигляд [8, с. 52]:

$$
\Pi_{\text {чuc }}=f\left(T_{p i u}, S_{p i u}, \Sigma \Pi O Д_{p i u}\right), г р н,
$$

де $T_{p i 4}$ - тарифна вартість перевезення річного вантажопотоку, грн;

$S_{p i ч}$ - річна собівартість перевезень, грн;

$\Sigma П О Д_{р і ч}-$ податки автотранспортного підприємства, грн.

Для виявлення резервів підвищення ефективності експлуатації вантажних автомобілів (в даному випадку прибутку власника рухомого складу) виконаємо аналіз змінних, що впливають на їі значення.

$T_{p i ч}$ - тарифна вартість перевезення річного вантажопотоку, грн, визначає валовий дохід або виручку від реалізації послуг робіт АТП з перевезення вантажів. Тарифна вартість перевезення визначається величиною тарифу, який $є$ ціною перевезень вантажів. В даний час тарифи формуються на ринкових умовах на основі витрат, попиту і пропозиції. Підвищення тарифу на перевезення 3 метою підвищення прибутку АТП може призвести до зворотного, коли клієнти можуть відмовитися від послуги на користь конкуруючих підприємств. Позитивний ефект використання цього ресурсу 
можливий тільки в тих випадках коли підприємство явно сильніше за конкурентів або є інші гарантії, що дають упевненість у збереженні клієнтської бази АТП.

$S_{p i ч}$ - річна собівартість перевезень. Для виявлення резервів для підвищення прибутку автотранспортних підприємств структурні складові статей собівартості необхідно розділити на дві підгрупи. У першу включають статті, величина яких безпосередньо залежить від технічних особливостей вантажних автомобілів. Це витрати на паливо, мастильні та інші експлуатаційні матеріали, витрати на знос і відновлення автомобільних шин і витрати на ТО і ремонт. У другу групу включають статті, величини яких визначаються організаційними особливостями функціонування АТП. Це заробітна плата водіїв, відрахування на соціальні потреби, амортизація рухомого складу і загальногосподарські витрати.

3 позиції знаходження резервів підвищення прибутку підприємства найбільший інтерес представляє перша група, оскільки величини значень цих статей варіюються в значних межах в залежності від типу, моделі, модифікації вантажних автомобілів.

$\Sigma П О Д_{р і ч}$ - податки транспортних підприємств. Виконаємо аналіз податків, що стягуються державою з автотранспортних підприємств. 3 валового прибутку стягуються податки: на прибуток (18\% від валового прибутку); на додану вартість - ПДВ (20\%); земельний (ставка податку за земельні ділянки, нормативну грошову оцінку яких проведено, встановлюється у розмірі не більше $3 \%$ від їх нормативної грошової оцінки).

Величина податків мало залежить від типу рухомого складу, отже, при виборі парку змінюватиметься мало. Таким чином, аналіз складових залежності (1) показав, що єдиній значимій змінній при формуванні залежності (1) прибутку АТП при виборі найбільш раціонального парку автомобілів є величина собівартості перевезень $S_{p i ч}$.

Собівартість перевезень характеризує широкий спектр факторів, що впливають на прибуток підприємства. Проаналізуємо статті собівартості, з метою виявлення параметрів що впливають на формування їі величини:

1) заробітна плата водіїв і відрахування на соціальні потреби. Величина цієї статті визначається чисельністю водіїв, зайнятих в перевізному процесі, формою оплати праці і її величиною.

Чисельність водіїв на заданий обсяг перевезень визначається за формулою [8, с. 54]:

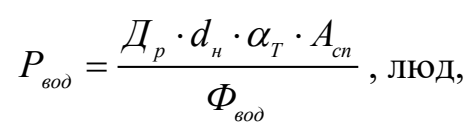

де $Д_{p}$ - кількість днів роботи АТП за рік, днів;

$d_{H}-$ тривалість робочого дня, год.;

$\alpha_{T}$ - коефіцієнт технічної готовності;

$A_{c n}$ - облікова кількість автомобілів АТП, од.;

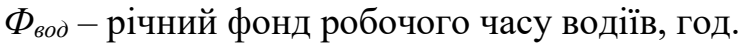

Як видно з формули (2) на кількість водіїв впливає форма організації перевізного процесу і фактична кількість автомобілів, що використовується в перевезеннях. Річний фонд робочого часу водіїв визначається кількістю робочих днів тривалістю робочої зміни.

Відрахування на соціальні потреби становлять $21,5 \%$ (22\% - ССВ + 1,5\% -військовий збір) від заробітної плати. Ці засоби мають соціальний характер, тобто безпосередньо визначають соціальну складову ефективності експлуатації автомобілів.

2) амортизація рухомого складу. Нині фонд амортизаційних відрахувань, навіть якщо він формується, може бути спрямований не просто на відновлення вартості автомобілів, а в цілому на розвиток підприємства, за бажанням керівництва підприємства;

3) автомобільне паливо. Витрати на автомобільне паливо визначається його вартістю i фактичною витратою при експлуатації вантажних автомобілів. Вартість палива встановлюється в ринкових умовах, тобто величиною попиту і пропозиції. Це мало керований підприємством і мало передбачуваний фактор, який залежить від сукупності процесів, що проходять в макроекономіці. Витрата палива при експлуатації вантажних автомобілів безпосередньо визначається їх технічними характеристиками, як техніко-експлуатаційними, так і технічним станом вантажних автомобілів [9].

Витрата палива визначається парком, моделлю вантажних автомобілів, умовами їх експлуатації, технічним станом автомобілів, характером перевезень, раціональністю маршрутів перевезень, парком вантажу, що перевозиться. Існуючі методики нормування витрати палива $[1 ; 3]$ 
враховують усі ці фактори, отже, облік їх у формуванні прибутку підприємства досить простий, але в той же час враховує безліч технічних і технологічних факторів;

4) мастильні та експлуатаційні матеріали. Величина цісї статті залежить від ціни цих матеріалів i їх ринкової вартості, отже ця стаття характеризує сукупність технічних і технологічних факторів, що впливають на формування прибутку, але в теж час досить просто визначається за існуючими методиками $[1 ; 3 ; 5 ; 6]$.

5) знос і ремонт автомобільних шин. Ця стаття собівартості враховує витрати підприємства поперше на закупівлю нових шин в заміні зношених і по-друге витрати на відновлення працездатності шин в процесі їх експлуатації. Витрати на шини визначаються [8, с. 55]:

$$
3_{u}=N_{u} \cdot L_{u}+\frac{H_{u}}{100} \cdot k_{u} \cdot L_{u} \cdot n_{u} \cdot \frac{L_{\text {заг }}}{1000}, \text { грн, }
$$

де $Ц_{u}$ - ціна одного комплекту шин (покришка, камера, ободна стрічка), грн;

$N_{u}$ - річний знос шин, од.;

$H_{u}$ - норма зносу і ремонту шин у \% до вартості комплекту на 1000 км пробігу \%;

$k_{m}$ - коефіцієнт коригування норми пробігу шин, що враховує умови експлуатації рухомого складу і перепробіг шин;

$n_{u}$ - кількість шин на автомобілів, од;

$L_{\text {заг }}$ - пробіг автомобіля за рік, км.

Перший доданок у формулі (3) характеризує вартість шини і їх кількість на автомобілі, тобто безпосередньо характеризує парк автомобіля, його модель і марку, а також перевагу власника автомобіля у встановлені тієї або іншої моделі шини на автомобіль. Тобто побічно характеризує виробничу потужність підприємства i організацію ремонтного виробництва. Другий доданок характеризує якість використовуваних на автомобілі шин, умови експлуатації автомобілів, якість роботи водіїв, режими роботи автомобілів. Таким чином, цей параметр враховує велику сукупність факторів, що впливають на прибуток підприємства i ефективність експлуатації вантажних автомобілів;

6) технічне обслуговування (ТО) i ремонт автомобілів. Розрахунок витрат на технічне обслуговування i ремонт вантажних автомобілів здійснюється через норми витрат, що встановлюються в грн на 1000 км пробігу. Дані норми були розроблені на деякі моделі автомобілів [10]. Нині дані норми можна використати з урахуванням індексації у відповідності з ринковою вартістю запасних частин i матеріалів i надійності автомобілів в умовах функціонування транспортних підприємств. Складніше визначати витрати для нових моделей імпортних вантажних автомобілів, для яких подібні норми встановлені не були. В цьому випадку на підприємстві необхідно організовувати роботи по накопиченню і обробці статистичної інформації по фактичній витраті запасних частин і ринкової їх вартості;

7) загальногосподарські витрати. Ця стаття собівартості експлуатації автомобілів приймається рівною $25 \%$ від суми витрат попередніх статей собівартості експлуатації автомобілів, а отже побічно враховує сукупність факторів, що впливають на прибуток підприємства і ефективність експлуатації автомобілів.

Значення статей собівартості також досить просто розраховуються за відомими методиками [5; $6 ; 9 ; 11-13]$.

Структура собівартості перевезень вантажів автомобілями [14]:

$$
\Sigma S=\left(S_{H P}+S_{\Pi B}+S+S_{x}\right) \cdot W_{Q}+R_{1}+R_{2}+R_{3}+R_{4}+R_{5}+R_{6}+R_{7}+R_{8}+R_{9}+R_{10}, \text { грн },
$$

де $W_{Q}$ - обсяг перевезень, т;

$S_{H P}$ - витрати на навантажувально-розвантажувальні роботи, грн/т;

$S_{\Pi B}-$ витрати на підготовку вантажу до перевезення, грн/т;

$S$ - витрати на транспортування 1 т вантажу, грн/т;

$S_{x}-$ витрати на складування вантажу, грн/т;

$R_{1}$ - витрати, пов'язані зі збільшенням відстані транспортування вантажу, грн;

$R_{2}$ - витрати унаслідок невідповідності рухомого складу роду і характеру вантажу, що перевозиться, грн;

$R_{3}$ - витрати, пов'язані з ушкодженням і втратою вантажу, грн;

$R_{4}$ - витрати, пов'язані 3 виконанням додаткового навантажувального-розвантажувальних робіт, грн; 
$R_{5}$ - витрати, пов'язані з додатковим зберіганням вантажу, грн;

$R_{6}$ - витрати, пов'язані з інерційністю транспортного процесу, грн;

$R_{7}$ - витрати, пов'язані зі збільшенням вартості транспортування, грн;

$R_{8}$ - витрати, пов'язані зі збільшенням вартості навантажувального-розвантажувальних робіт, грн;

$R_{9}$ - витрати, пов'язані зі збільшенням вартості підготовки вантажу до перевезення, грн;

$R_{10}$ - витрати, пов'язані зі збільшенням вартості складування вантажу, грн.

Витрати на транспортування вантажу мають наступну структуру [12; 13]:

$$
S=S_{\Pi}+S_{M M}+S_{T O P}+S_{\amalg}+S_{A M}+S_{H}+S_{Д,}, г р н,
$$

де $S_{\Pi}-$ витрати на паливо, грн;

$S_{M M}$ - витрати на мастильні та інші експлуатаційні матеріали, грн;

$S_{T O P}-$ витрати на ТО і ремонт, грн;

$S_{\amalg}-$ витрати на відновлення зносу і ремонт шин, грн;

$S_{A M}-$ витрати на амортизацію, грн;

$S_{H}-$ накладні витрати, грн;

$S_{д}-$ витрати на податки, грн.

Ці експлуатаційні витрати на вантажні перевезення автомобілями, можна розділити на умовнотехнічні витрати $(У T B)$ - змінні: $S_{\Pi}, S_{M M}, S_{T O P}, S_{\amalg}$ та умовно-організаційні витрати $(У O B)$ - умовнопостійні: $S_{A M}, S_{H}, S_{\text {д. }}$ Остання група складових змінюється при оновленні парку автомобілів приблизно однаково при будь-якому варіанті вибору, тому при подальших розрахунках нею можна нехтувати.

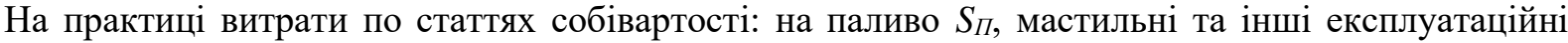
матеріали $S_{M M}$ і відновлення зношених і ремонт шин $S_{\amalg}$ визначаються по існуючих методиках, і в достатній мірі відповідають фактичним виробничим значенням $[2 ; 4-6 ; 10 ; 12 ; 15]$. Витрати на ТО і

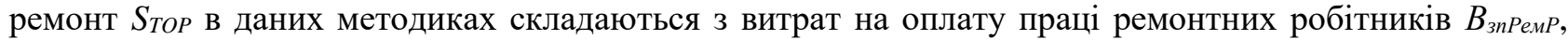
витрат на запасні частини і матеріали Взчім. Витрати на ТО і ремонт розраховуються, виходячи 3 питомих норм на конкретні моделі автомобілів $H_{\text {тоір }}$, грн/1000 км. Наявні значення цієї норми були розроблені на застарілі моделі автомобілів і в даний час використовуються 3 урахуванням коефіцієнтів індексації, на зарубіжні моделі автомобілів і сучасні вітчизняні їх зовсім немає. Крім

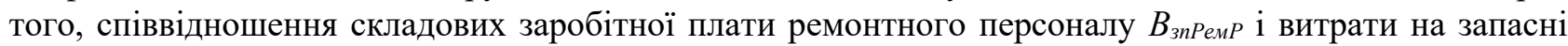
частини і матеріали $B_{3 ч і м}$ в питомих нормах $H_{\text {тоіР }}$ нині змінилися в порівнянні з тими, які були закладені при їх розробці на початку 90 -х років XX ст. У даних нормах частка витрат на заробітну плату ремонтних робітників розраховувалась на основі тарифних ставок слюсаря 3-го розряду і на них припадало $30-40 \%$, на запасні частини і матеріали $60-70 \%$. Нині 3 причини різного рівня годинних тарифних ставок ремонтних робітників на підприємствах, які можуть значно відрізнятися

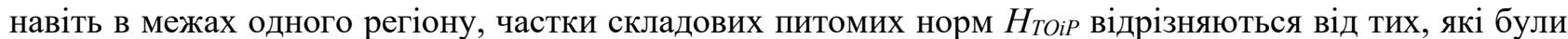
розроблені раніше. Тому в цю статтю витрат включатимемо тільки витрати на запасні частини і матеріали, що використовуються при ТО і ремонті автомобілів, позначивши їх $-S_{3 ч і м}$. Витрати на

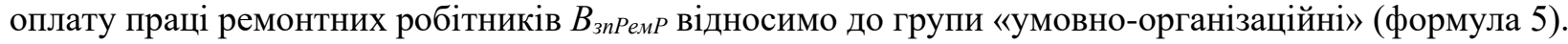

Тоді умовно-технічні витрати мають вигляд $[8$, с. 58$]$ :

$$
y T B=S_{\Pi}+S_{M M}+S_{\amalg}+S_{3 \varphi_{i M},}, \text { грн, }
$$

Цей показник використання вантажних автомобілів опосередковано враховує в грошовому еквіваленті:

1) конструктивні особливості автомобіля, безпосередньо пов’язані з роботою рухомого складу на лінії;

2) фактичну надійність автомобіля в конкретних умовах функціонування АТП;

3) ефективність автомобіля до конкретних умовах експлуатації;

4) вартість і витрату запасних частин і матеріалів для конкретної моделі автомобіля.

Цей показник дозволяє:

1) оцінювати ефективність використання автомобілів в грошовому еквіваленті;

2) порівнювати ефективність різних марок і моделей автомобілів в грошовому еквіваленті;

3) вибирати найбільш раціональний парк рухомого складу;

4) побічно оцінювати ефективність роботи служби експлуатації автомобілів на різних АТП в грошовому еквіваленті. 
Проаналізувавши умовно-технічні витрати $(У T B)$ при використанні автомобілів, отримуємо. 1) витрати на паливо [8, с. 59]:

$$
S_{\Pi}=B_{\Pi} \cdot Q_{\Pi}=B_{\Pi} \cdot 0,01 \cdot\left(H_{L} \cdot L+H_{m \kappa n} \cdot W\right)(1+0,01 \cdot k), \text { грн, }
$$

де $B_{\Pi}-$ вартість 1 л палива, грн;

$Q_{\Pi}-$ витрата палива, л;

$H_{L}$ - норма витрати палива автомобіля, л/100 км;

$L-$ пробіг автомобіля за звітний період, км;

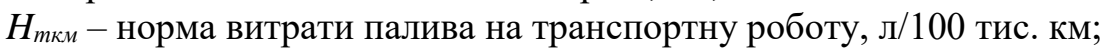

$k$ - надбавка, що враховує умови експлуатації, \%.

$W$ - обсяг транспортної роботи, тис. км.

$$
W=Q_{B} \cdot L_{E B} \text {, тис. км, }
$$

де $Q_{B}-$ маса вантажу, т; $L_{E B}-$ пробіг з вантажем, км.

Тоді [8, с. 59]:

$$
S_{T}=B_{\Pi} \cdot Q_{\Pi}=B_{\Pi} \cdot 0,01 \cdot\left(H_{L} \cdot L+H_{\text {тки }} \cdot Q_{B} \cdot L_{E B}\right)(1+0,01 \cdot k), \text { грн, }
$$

2 ) витрати на мастильні матеріали $[8$, c. 60$]$ :

$$
S_{M M}=B_{M M} \cdot Q_{M M}=0,01 \cdot B_{\Pi} \cdot Q_{\Pi} \cdot H_{M M}, \Gamma \mathrm{pH},
$$

де $B_{M M}$ - вартість 1 л (кг) мастильного матеріалу, грн;

$Q_{M M}$ - витрата мастильного матеріалу, л (кг);

$H_{M м}$ - норма витрати мастильного матеріалу, л(кг)/100 л палива.

3) витрати на шини $[8$, с. 60]:

де $B_{\amalg}-$ вартість шини, грн;

$$
S_{\amalg}=B_{\Psi} \cdot N_{\Psi}+0,01 \cdot H_{\Psi} \cdot k_{W} \cdot n_{\Psi} \cdot(0,001 L), \text { грн, }
$$

$N_{\amalg}$ - витрата шин, од.;

$H_{\amalg}$ - норма зносу і ремонту шин в \% до вартості комплекту на 1000 км пробігу, \%;

$k_{\amalg}-$ коефіцієнт коригування норми пробігу шин, що враховує умови експлуатації рухомого складу і перепробіг шин;

$n_{\amalg}$ - кількість шин на автомобілів, од.;

$L-$ пробіг автомобіля за звітний період, км.

У свою чергу річна витрата шин [8, с. 60]:

$$
N_{U}=\frac{n_{W} L}{L_{H}},
$$

де $L_{H}-$ нормативний пробіг шини, км; $L-$ пробіг автомобіля за звітний період, км.

Тоді $[8$, с. 60$]$ :

$$
S_{U}=B_{U} \cdot \frac{n_{U}}{L_{H}}+0,001 \cdot H_{U} \cdot k_{U} \cdot n_{W} \cdot(0,001 \cdot L), \text { грн, }
$$

4) витрати на запасні частини і матеріали, що використовуються при ТО і ремонті [8, с. 61]:

$$
S_{3 ч i м}=L \cdot B_{3 ч і м}, \text { грн, }
$$

де $L$ - пробіг автомобіля за звітний період, км;

$B_{3 ч і м}$ - питомі витрати на запасні частини і матеріали, грн/км.

Для визначення величини УТВ використовуються формули (9), (10), (13). Помноживши отримані формули на вартість даних матеріалів $C_{i}$, грн/од. матеріалу отримаємо абсолютні їх значення. Для приведення до порівнянного виду, при порівнянні автомобілів за цим показником, його необхідно розділити на обсяг виконуваної вантажної транспортної роботи за звітний період $W$, ткм. Тоді формула (6) для питомих умовно-технічних витрат на експлуатацію автомобіля при доставці вантажів можна записати у вигляді $[8$, с. 61$]$ : 
$\Pi У Т В=\frac{1}{W} \cdot\left[\left(B_{\Pi} \cdot 0,01 \cdot\left(H_{L} \cdot L+H_{m к и} \cdot Q_{B} L_{E P}\right) \cdot(1+0,01 \cdot k)+B_{M M} \cdot 0,01 \cdot Q_{\Pi} \cdot H_{M M}+B_{U I} \cdot \frac{n_{U I} \cdot L}{L_{H}}+\right.\right.$

$\left.\left.+0,0,01 \cdot H_{\amalg}+k_{U} \cdot n_{\amalg} \cdot L+L \cdot B_{3 ч і м}\right)\right]$, грн/тис. км

де $W$ - обсяг, виконуваної вантажної транспортної роботи за звітний період, тис. км;

$B_{\Pi}$ - вартість 1 л палива, грн; $H_{L}$ - базова норма витрати палива, л/100 км;

$L-$ пробіг автомобіля за досліджуваний період, км;

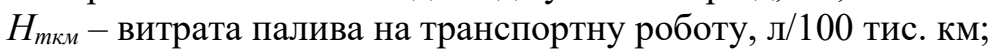

$Q_{B}$ - маса вантажу, що перевозиться, т;

$L_{E B}$ - пробіг з вантажем, км;

$k$ - надбавка, що враховує умови експлуатації \%;

$B_{M м}$ - вартість 1 л(кг) мастильних матеріалів, грн;

$H_{M M}$ - норма витрати мастильного матеріалу, л (кг)/100 л палива;

$B_{\amalg}-$ вартість шини, грн;

$n_{\amalg}$ - кількість шин на автомобілі, од.;

$L-$ пробіг автомобіля за звітний період, км;

$L_{H}$ - нормативний пробіг шини, км;

$H_{\amalg}$ - норма зносу і ремонту шин в \% до вартості комплекту на 1000 км пробігу \%;

$k_{\amalg}$ - коефіцієнт коригування норми пробігу шин, що враховує умови експлуатації рухомого складу і перепробіг шин;

$B$ зчім - питомі витрати на запасні частини і матеріали, грн/км.

Спростимо формулу (5), позначивши:

Д $=(1+0,01 \cdot k)$ - надбавка на витрату палива залежно від умов роботи;

$B_{\Pi}^{\Pi A}=L \cdot H_{L}-$ витрата палива автомобілів без вантажу;

$B_{\Pi}^{B}=H_{m к м} \cdot Q_{B} \cdot L_{E B}-$ витрата палива на транспортну роботу;

$3_{\Psi}=\frac{n_{W} \cdot L}{L_{H}}-$ знос (витрата) автомобільних шин;

$B_{B}^{W I}=0,01 \cdot H_{\amalg I} \cdot k_{\amalg} \cdot n_{\amalg I} \cdot(0,001 \cdot L)-$ витрати на відновлення шин.

Тоді отримуємо формулу [8, с. 62]:

$$
\begin{aligned}
& \Pi У Т В=\frac{1}{W} \cdot\left[B_{\Pi} \cdot 0,01 \cdot\left(P_{\Pi}^{\Pi A}+P_{\Pi}^{B}\right) \cdot Д+B_{M M} \cdot 0,01 \cdot\left(P_{\Pi}^{\Pi A}+P_{\Pi}^{B}\right) \cdot H_{M M}+B_{\amalg} \cdot 3_{\amalg}+\right.
\end{aligned}
$$

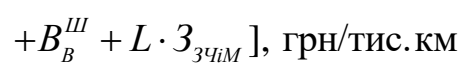

При оцінці варіантів оновлення парку рухомого складу рекомендується в якості основного критерію використати величину господарського економічного ефекту, яка визначається як різниця співрозмірних приведених річних витрат [8, с. 62]:

$$
E_{\Gamma}=\left(S_{1}+E_{H} \cdot K_{1}\right)-\left(S_{2}+E_{H} \cdot K_{2}\right)=S_{1}-S_{2} \pm E_{H} \cdot \Delta K, \text { грн, }
$$

де $S_{1}, S_{2}$ - поточні річні виробничі витрати по 1-у і 2-у варіантах, грн;

$K_{1}, K_{2}$ - капітальні вкладення по варіантах, грн;

$\Delta K$ - різниця капітальних вкладень, грн;

$E_{H}-$ коефіцієнт приведення капітальних вкладень по варіантах до поточних річних виробничих витрат.

Тоді ефект, що досягається власником парку комерційних вантажних автомобілів $E_{B \Pi 3}^{B}$, грн, при його оновленні може бути виражений як [8, с. 63]:

$$
E_{B \Pi 3}^{B}=\left(У T B_{1}+E_{H} \cdot K_{1}\right)-\left(У T B_{2}+E_{H} \cdot K_{2}\right)=У T B_{1}-У T B_{2} \pm E_{H} \cdot \Delta K, \text { грн, }
$$

де $Y T B_{1}, V T B_{2}$ - умовно технічні складові експлуатаційних витрат на транспортування вантажів по 1-у (базовому) і 2-у (новому) варіантам.

Значення коефіцієнта $E_{H}$ в наш час потрібно розуміти як рознесення вартості капітальних вкладень по роках їх реалізації. Отже, величина цього коефіцієнта визначатиметься безпосередньо на виробництві, індивідуально для кожного автомобіля. За умови, що вибрані для експлуатації 
автомобілі знаходяться в одній ціновій категорії і експлуатуватимуться однакову кількість років, коефіцієнтом в нашому випадку можна нехтувати. Тоді річний ефект власника рухомого складу $E_{B I 3}^{B}$, що досягається при введені в експлуатацію моделей автомобілів з меншими УТВ (за умови рівності усіх інших складових, що впливають на прибуток підприємства):

$$
E_{B I 3}^{B}=\triangle У T B=У T B_{1}-У T B_{2}, \text { грн }
$$

Питомий ефект $E_{B П 3}^{B}($ грн/тис. км) дорівнює [8, с. 63]:

$$
E_{\text {вПз }}=\Delta П У T B=\frac{1}{W} \cdot\left(У T B_{1}-У T B_{2}\right), \text { грн/тис. км, }
$$

де $W$ - обсяг транспортної роботи, що реалізовується автомобілями, тис. км.

Різниця витрат на паливо [8, с. 63]:

$$
\begin{aligned}
& \Delta S_{\Pi}=B_{\Pi_{1}} \cdot 0,01 \cdot\left(P_{\Pi_{1}}^{\Pi A}+P_{\Pi_{1}}^{B}\right) \cdot Д_{1}-B_{\Pi_{2}} \cdot 0,01 \cdot\left(P_{\Pi_{2}}^{\Pi A}+P_{\Pi_{2}}^{B}\right) \cdot Д_{2}= \\
& =0,01 \cdot B_{\Pi_{1}} \cdot P_{\Pi_{1}}^{\Pi A} \cdot Д_{1}+0,01 \cdot B_{\Pi_{1}} \cdot P_{\Pi_{1}}^{B} \cdot Д_{1}-0,01 \cdot B_{\Pi_{2}} \cdot P_{\Pi_{2}}^{\Pi A} \cdot Д_{2}-0,01 \cdot B_{\Pi_{2}} \cdot P_{\Pi_{2}}^{B} \cdot Д_{2}, \text { грн }
\end{aligned}
$$

Позначимо: $Q_{S_{1}}^{\Pi A}=P_{\Pi_{1}}^{\Pi A} \cdot Д_{1} ; Q_{S_{1}}^{B}=P_{\Pi_{1}}^{B} \cdot Д_{1} ; Q_{S_{2}}^{\Pi A}=P_{\Pi_{2}}^{\Pi A} \cdot Д_{2} ; Q_{S_{2}}^{B}=P_{\Pi_{2}}^{B} \cdot Д_{2}$.

Тоді:

$$
\Delta S_{\Pi}=0,01 \cdot B_{\Pi_{1}} \cdot\left(Q_{S_{1}}^{\Pi A}-Q_{S_{1}}^{B}\right)-0,01 \cdot B_{\Pi_{2}} \cdot\left(Q_{S_{2}}^{\Pi A}-Q_{S_{2}}^{B}\right)
$$

Введемо відносний коефіцієнт порівняння:

$$
K_{i}=\frac{S_{i}^{H}}{S_{i}^{\sigma}}
$$

де $S_{i}, S_{i}^{\sigma}-$ значення $i$-ї статті витрат відповідно нового і базового варіанту.

Відповідно: $\quad K_{B_{\Pi}}=\frac{B_{\Pi_{1}}}{B_{\Pi_{2}}}-$ критерій оцінки за вартістю палива. Тоді: $B_{\Pi_{1}}=K_{B \Pi} \cdot B_{\Pi_{2}}$; $K_{Q_{S}}=\frac{Q_{S_{1}}^{\Pi A}-Q_{S_{1}}^{B}}{Q_{S_{2}}^{\Pi A}-Q_{S_{2}}^{B}}-$ критерій оцінки по витраті палива. Тоді: $Q_{S_{1}}^{\Pi A}-Q_{S_{1}}^{B}=K_{Q_{S}} \cdot\left(Q_{S_{2}}^{\Pi A}-Q_{S_{2}}^{B}\right)$.

Отже:

$$
\begin{aligned}
& \Delta S_{\Pi}=0,01 \cdot\left(K_{B_{\Pi}} \cdot B_{\Pi_{2}} \cdot K_{Q_{S}} \cdot\left(Q_{S_{2}}^{\Pi A}-Q_{S_{2}}^{B}\right)-B_{\Pi_{2}} \cdot\left(Q_{S_{2}}^{\Pi A}-Q_{S_{2}}^{B}\right)\right)= \\
& =0,01 \cdot B_{\Pi_{2}} \cdot\left(Q_{S_{2}}^{\Pi A}-Q_{S_{2}}^{B}\right) \cdot\left(K_{B_{\Pi}} \cdot K_{Q_{S}}-1\right), \text { грн }
\end{aligned}
$$

Різниця витрат на мастильні матеріали $[8$, с. 65$]$ :

$$
\begin{aligned}
& \Delta S_{M M}=B_{M M_{1}} \cdot\left(0,001 \cdot\left(P_{\Pi_{1}}^{\Pi A}+P_{\Pi_{1}}^{B}\right) \cdot Д_{1}\right) \cdot H_{M M_{1}}-B_{M M_{2}} \cdot\left(0,001 \cdot\left(P_{\Pi_{2}}^{\Pi A}+P_{\Pi_{2}}^{B}\right) \cdot Д_{2}\right) \cdot H_{M M_{2}}= \\
& =0,001 \cdot B_{M M_{1}} \cdot\left(Q_{S_{1}}^{\Pi A}-Q_{S_{1}}^{B}\right) \cdot H_{M M_{1}}-0,001 \cdot B_{M M_{2}} \cdot\left(Q_{S_{2}}^{\Pi A}-Q_{S_{2}}^{B}\right) \cdot H_{M M_{2}}, \text { грн }
\end{aligned}
$$

Положимо: $K_{B_{M M}}=\frac{B_{M M_{1}}}{B_{M M_{2}}}-$ критерій оцінки за мастильного матеріалу. Тоді: $B_{M M_{1}}=K_{M M} \cdot B_{M M_{2}}$; $K_{Q_{S}}=\frac{Q_{S_{1}}^{\Pi A}-Q_{S_{1}}^{B}}{Q_{S_{2}}^{\Pi A}-Q_{S_{2}}^{B}}-$ критерій оцінки по витраті палива. Тоді: $Q_{S_{1}}^{\Pi A}-Q_{S_{1}}^{B}=K_{Q_{s}} \cdot\left(Q_{S_{2}}^{\Pi A}-Q_{S_{2}}^{B}\right)$. Аналогічно: $K_{H_{M M}}=\frac{H_{M M_{1}}}{H_{M M_{2}}}-$ критерій оцінки по нормі витрати мастильного матеріалу. Тоді: $H_{M M_{1}}=K_{H_{M M}} \cdot H_{M M_{2}}$. 
Отже [8, c. 66]:

$$
\begin{aligned}
& \Delta S_{M M}=0,001 \cdot\left(K_{M M} \cdot B_{M M_{2}} \cdot K_{Q_{S}} \cdot\left(Q_{S_{2}}^{\Pi A}-Q_{S_{2}}^{B}\right) \cdot K_{H_{M M}} \cdot H_{M M_{2}}-B_{M M_{2}} \cdot\left(Q_{S_{2}}^{\Pi A}-Q_{S_{2}}^{B}\right) \cdot H_{M M_{2}}=\right. \\
& =0,001 \cdot B_{M M_{2}} \cdot\left(Q_{S_{2}}^{\Pi A}-Q_{S_{2}}^{B}\right) \cdot H_{M M_{2}} \cdot\left(K_{M M} \cdot K_{Q_{S}} \cdot K_{H_{M M}}-1\right), \text { грн }
\end{aligned}
$$

Різниця витрат на шини:

$$
\Delta S_{W_{1}}=B_{U_{1}} 3_{U_{1}}-B_{U_{2}} 3_{U_{2}}
$$

Виразимо: $K_{B_{U l}}=\frac{B_{U_{1}}}{B_{U_{2}}}-$ критерій оцінки за вартістю автомобільних шин. Тоді: $B_{U_{1}}=K_{B_{U l}} \cdot B_{U_{2}}$ $; K_{3_{\Perp}}=\frac{3_{\Psi_{1}}}{3_{\Psi_{2}}}-$ критерій оцінки по зносу (витраті) шин. Тому: $3_{\Psi_{1}}=K_{3_{u}} \cdot 3_{\Psi_{2}}$. Відповідно:

$$
\Delta S_{U}=K_{U} \cdot B_{U_{2}} \cdot K_{3_{U}} \cdot 3_{U_{2}}-B_{U_{2}} \cdot 3_{U_{2}}=B_{U_{2}} \cdot 3_{U_{2}} \cdot\left(K_{B_{U I}} \cdot K_{3_{U I}}-1\right), \text { грн }
$$

Різниця витрат на відновлення шин $[8$, с. 66$]$ :

$$
\Delta S_{B}^{W I}=B_{B_{1}}^{W I}-B_{B_{2}}^{W I}
$$

Виразимо: $K_{3_{B}^{U}}=\frac{B_{B_{1}}^{W I}}{B_{B_{2}}^{W I}}-$ критерій оцінки за по витратам на відновлення автомобільних шин. Тоді: $B_{B_{1}}^{W I}=K_{3_{B}^{U I}} \cdot B_{B_{2}}^{W I}$. Відповідно:

$$
\Delta S_{B}^{U I}=K_{3_{B}^{U I}} \cdot B_{B_{2}}^{U I}-B_{B_{2}}^{U I}=B_{B_{2}}^{U I} \cdot\left(K_{3_{B}^{U U}}-1\right), \text { грн }
$$

Різниця витрат на запасні частини і матеріали при однаковому пробігу порівнюваних автомобілів $L_{3 A \Gamma}($ км):

$$
\Delta S_{3 \varphi_{i M}}=L \cdot\left(B_{3 \text { qi }_{1}}-B_{3 \text { чi }_{2}}\right), \text { грн }
$$

По аналогії з попередніми виразами перетворимо, тоді:

$$
\Delta S_{3 \varphi_{i M}}=L \cdot B_{34_{i M_{2}}} \cdot\left(K_{3 \varphi_{i M_{1}}}-1\right), \text { грн }
$$
67]:

Перетворимо формулу (20) з урахуванням формул (24), (26), (28), (30) і (32), отримаємо [8, с.

$$
\begin{aligned}
& \Delta \Pi У T B=\frac{1}{W} \cdot\left[0,001 \cdot B_{\Pi_{2}} \cdot\left(Q_{S_{2}}^{\Pi A}-Q_{S_{2}}^{B}\right) \cdot\left(K_{B_{\Pi}} \cdot K_{Q_{S}}-1\right)+\right. \\
& +0,001 \cdot B_{M M_{2}} \cdot\left(Q_{S_{2}}^{I A}-Q_{S_{2}}^{B}\right) \cdot H_{M M_{2}} \cdot\left(K_{M M} \cdot K_{Q_{S}} \cdot K_{H_{M M}}-1\right)+ \\
& \left.+B_{M M_{2}} \cdot B_{U_{2}} \cdot\left(K_{B_{U I}} \cdot K_{3_{U I}}-1\right)+B_{B_{2}}^{W U} \cdot\left(K_{3_{B}^{U U}}-1\right)+L \cdot B_{3 \text { чi }_{2}} \cdot\left(K_{\text {зчім }}-1\right)\right] \text {, грн/тис. км }
\end{aligned}
$$

Позначимо: $B_{\Pi_{2}}=0,01 \cdot B_{\Pi_{2}} \cdot\left(Q_{S_{2}}^{\Pi A}-Q_{S_{2}}^{B}\right)$ - витрати на паливо нового варіанту автомобіля; $B_{M M_{2}}=0,001 \cdot B_{M M_{2}} \cdot\left(Q_{S_{2}}^{I A}-Q_{S_{2}}^{B}\right) \cdot H_{M M_{2}}-$ витрати на мастильні матеріали нового варіанту автомобіля. Тоді питомі умовно-технічні витрати при транспортуванні вантажів (ПУТВ $\left.{ }_{1 i}\right)$ можна записати таким чином - ПУТВ ${ }_{1 i}=K_{1} \Pi У T B_{2 i}$. Підставляючи цей вираз у формулу (20) отримаємо величину питомого ефекту при заміні базової моделі автомобіля на новий варіант:

$$
E_{B P C}=\triangle \Pi У T B=K_{i} \cdot \Pi У T B_{2_{i}}-\Pi У T B_{2_{i}}=\Pi У T B_{2_{i}} \cdot\left(K_{i}-1\right), \text { грн/тис. км }
$$


де ПУТВ - питомі умовно-технічні витрати при експлуатації нового варіанту автомобіля в парку рухомого складу, грн/тис. км.

Розкриваючи цей вираз з урахуванням прийнятих позначень, отримаємо величину річного економічного ефекту, що досягається власником вантажних автомобілів при оновленні парку [8, с. 68]:

$$
\begin{aligned}
& E_{B P C}=\triangle \Pi У T B=\frac{1}{W} \cdot \sum_{i=1}^{n}\left[B_{\Pi_{2}} \cdot\left(K_{B_{\Pi}} \cdot K_{Q_{S}}-1\right)+B_{M M_{2}} \cdot\left(K_{B_{M M}} \cdot K_{H_{M M}}-1\right)+\right.
\end{aligned}
$$

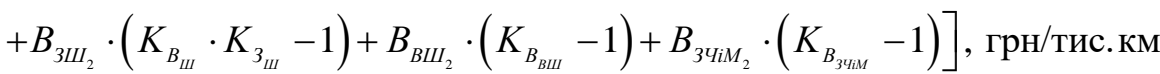

де $B_{\Pi_{2}}-$ витрати на паливо, грн;

$B_{M M_{2}}-$ витрати на мастильні і інші експлуатаційні матеріали, грн;

$B_{3 \Psi_{2}}-$ витрати на шини, грн;

$B_{\text {BШ }_{2}}-$ витрати на ремонт і відновлення шин, грн;

$B_{\text {зчім }}-$ витрати на запасні частини і матеріали, грн;

відносні коефіцієнти порівняння варіантів, відповідно:

$K_{B_{\Pi}}-$ за вартістю палива;

$K_{Q_{S}}-$ по витраті палива;

$K_{B_{u}}$ - за вартістю мастильних матеріалів;

$K_{B_{u v}}-$ по витраті мастильних матеріалів;

$K_{B_{B U}}-$ за вартістю комплекту шин;

$K_{B_{U}}-$ витраті шин;

$K_{3_{\Perp}}-$ за витратами на відновлення і ремонт шин;

$K_{B_{\text {зчім }}}-$ за витратами на запасні частини і матеріали.

При визначенні економічного ефекту $E_{B P C}$ для парку автомобілів необхідно виконати підсумовування по усіх автомобілях.

\section{ОБГОВОРЕННЯ РЕЗУЛЬТАТІВ ДОСЛІДЖЕННЯ}

Отже, методика розрахунку ефективності експлуатації вантажних автомобілів грунтується на величині чистого прибутку, який може отримати АТП при використанні наявного РС. Основним показником, який впливає на величину чистого прибутку $є$ річна собівартість перевезень. В структуру собівартості перевезень вантажів автомобілями входять такі складові, як: витрати на навантажувально-розвантажувальні роботи, витрати на підготовку вантажу до перевезення, витрати на транспортування вантажу і 10 показників, якими визначаються «незаплановані» витрати (витрати, пов'язані 3 ушкодженням і втратою вантажу; витрати, пов’язані зі збільшенням вартості транспортування і т.д.)

Витрати на транспортування вантажу є комплексним показником, який поділяється на дві групи: 1) умовно-технічні витрати (УТВ) - змінні; 2) умовно-організаційні (УОВ) - умовно-постійні. Величина умовно-технічних витрат залежить від в свою чергу від 4-х статей витрат: 1) на паливо, 2) на мастильні та інші експлуатаційні матеріали, 3) на ремонт шин, 4) на запасні частини і матеріали при ТО і ремонтах.

У випадку оновлення парку РС величина річного економічного ефекту залежить від різниці між умовно-технічними витратами при базовому і новому варіантах РС.

\section{ВИСНОВКИ}

Розглянуті складові методики розрахунку ефективності експлуатації вантажних автомобілів дають можливість виконувати оцінку доцільності використання наявного РС в АТП або здійснювати його оновлення в залежності від обсягів і собівартості перевезень. При цьому основним критерієм для прийняття рішення про оновлення РС в АТП є величина умовно-технічних витрат. 


\section{ПЕРЕЛІК ДЖЕРЕЛ ПОСИЛАННЯ}

1. Великанов Д.П. Эффективность автомобильных транспортных средств и транспортной энергетики. Избранныле труды. Москва : Наука, 1989. 198 с.

2. Гончарук О.В. Экономическая эффективность транспортно-технологических систем. Москва : Наука, 1991. $128 \mathrm{c.}$

3. ГСМ: нормы расхода, бухгалтерский учёт и налогообложение / под ред. Ю.С. Касьяновой. Москва : АБАК, 2010. 128 с.

4. Домнина С.В. Особенности определения затрат при выполнении международных автомобильных перевозок автомобильным транспортом. Москва : Изд-во АСМАП. 1998. 96 с.

5. Корчагин В.А., Птицын Д.В. Расчёт экономической эффективности внедрения новой техники на автотранспортных предприятиях. Киев : Техника, 1980. 104 с.

6. Корчагин В.А., Бондаренко Е.В., Ризаева Ю.Н. Оценка эффективности инженерных решений. Липецк : ЛТУ, 2007. 160 с.

7. Рассоха В.И. Ситуационное управление автотранспортными системами (Часть 1. Системная эффективность эксплуатации автомобильного транспорта). Вестник ОГУ. Оренбург, 2009. №9. С. $148-153$.

8. Мигачев В.А. Повышение эффективности использования грузовых автомобилей на основе выбора наиболее рационального парка подвижного состава : дис. ... канд. техн. наук : 05.22.10. Пенза, Ульяновск, 2012. 137 с.

9. Фасхиев Х.А., Крахмалева А.В., Сафарова М.А. Конкурентоспособность автомобилей и их агрегатов. Набережные Челны, 2005. 152 с.

10. Голованенко С.Л., Жарова О.М., Маслова Т.И., Посыпай В.Г. Справочник инженераэкономиста автомобильного транспорта / под общ. ред. С. Л. Голованенко. Москва : Транспорт, 1984. $319 \mathrm{c}$.

11. Пеньшин Н.В. Эффективность и качество как фактор конкурентоспособности услуг на автомобильном транспорте : монография / под ред. В.П. Бычкова. Тамбов : Изд-во Тамб. гос. техн. ун-та, 2008. 224 с.

12. Трусова Л.И., Богданов В.В., Щепочкин В.А. Экономика автотранспортного предприятия : учеб. пособие. Ульяновск : УлГТУ, 2010. 65 с.

13. Фасхиев Х.А., Нуретдинов Д.И. Экономическая эффективность, качество и конкурентоспособность транспортных средств : учеб. пособие. Набережные Челны, 2009. 152 с.

14. Вельможин А.В., Гудков В. А., Миротин Л.Б., Куликов А.В. Грузовые автомобильные перевозки : учеб. Москва : Горячая линия-Телеком, 2016. 560 с.

15. Бычков В.П. Экономика автотранспортного предприятия : учеб. Москва : Инфра-М, 2006. $381 \mathrm{c}$.

\section{REFERENCES}

1. Velikanov D.P. (1989). Efficiency of Automotive Vehicles and Transportation Energy. [Jeffektivnosti avtomobilnyh transportnyh sredstv i transportnoj jenergetiki] Moscow : Nauka Publ. 198 p.

2. Goncharuk O.V. (1991). Economic efficiency of transport and technological systems. [Jekonomicheskaja jeffektivnosti transportno-tehnologicheskih sistem] Moscow, Nauka Publ. 128 p.

3. Ju.S. Kasjanova (2010). Fuel and lubricants: consumption rates, accounting and taxation. [GSM: normy rashoda, buhgalterskij uchjot i nalogooblozhenie] Moscow, ABAK Publ. 128 p.

4. Domnina S.V. (1998). Features of determining costs when performing international road transport by road. [Osobennosti opredelenija zatrat pri vypolnenii mezhdunarodnyh avtomobilnyh perevozok avtomobilnym transportom] Moscow, ASMAP Publ. 96 p.

5. Korchagin V.A., Pticyn D.V. (1980). Calculation of the economic efficiency of the introduction of new technology at road transport enterprises. [Raschjot jekonomicheskoj jeffektivnosti vnedrenija novoj tehniki na avtotransportnyh predprijatijah] Kiev : Tehnika Publ. 104 p.

6. Korchagin V.A., Bondarenko E.V., Rizaeva Ju.N. (2007). Evaluation of the effectiveness of engineering solutions. [Ocenka jeffektivnosti inzhenernyh reshenij] Lipeck : LTU Publ. $160 \mathrm{p}$.

7. Rassokha V.I. (2009). Situational management of motor vehicle systems. [Situacionnoe upravlenie avtotransportnymi sistemami. Chast 1 . Sistemnaja jeffektivnosti jekspluatacii avtomobilnogo transporta] Vestnik OGU. No. 9, Orenburg Publ. pp. 148-153.

8. Migachev V.A. (2012). Increasing the efficiency of the use of trucks based on the selection of the most rational fleet of rolling stock. Doct. Diss. [Povyshenie jeffektivnosti ispol'zovanija gruzovyh 
avtomobilej na osnove vybora naibolee racionalnogo parka podvizhnogo sostava. Dokt, Diss.] Penza, Uljanovsk. 137 p.

9. Faskhiev H.A., Krahmaleva A.V., Safarova M.A. (2005). Competitiveness of cars and their units. [Konkurentosposobnosti avtomobilej i ih agregatov] Naberezhnye Chelny. 152 p.

10. Golovanenko S.L., Zharova O.M., Maslova T.I., Posypaj V.G. (1984). Handbook of an engineereconomist of road transport. [Spravochnik inzhenera-jekonomista avtomobilnogo transporta] / under total. ed. S.L. Golovanenko. Moscow, Transport Publ. 319 p.

11. Penshin N.V. (2008). Efficiency and quality as a factor in the competitiveness of road transport services. [Jeffektivnost i kachestvo kak faktor konkurentosposobnosti uslug na avtomobilnom transporte. Monografija] under total. ed. V.P. Bychkov. Tambov, Tambov State Technical University Publ. 224 p.

12. Trusova L.I., Bogdanov V.V., Shhepochkin V.A. (2010). Economy of a trucking company. [Jekonomika avtotransportnogo predprijatija. Uchebnoe posobie] Uljanovsk : UlGTU Publ. 65 p.

13. Faskhiev H.A., Nuretdinov D.I. (2009). Economic efficiency, quality and competitiveness of vehicles. [Jekonomicheskaja jeffektivnosti, kachestvo i konkurentosposobnosti transportnyh sredstv. Uchebnoe posobie] Naberezhnye Chelny. 152 p.

14. Velmozhin A.V., Gudkov V.A., Mirotin L.B., Kulikov A.V. (2016). Freight road transport. [Gruzovye avtomobilnye perevozki. Uchebnik] Moscow, Gorjachaja linija-Telekom Publ. 560 p.

15. Bychkov V.P. (2006). The economics of a trucking company. [Jekonomika avtotransportnogo predprijatija. Uchebnik] Moscow, Infra-M Publ. 381 p.

\section{Khavruk, O. Parkhomenko. Method of calculating the efficiency of operation trucks.}

The paper considers the issue of assessing the efficiency of operation of trucks. It is established that the efficiency of car operation is functionally related to the economic efficiency, reliability and reliability of cars the relationship between which is presented in the form of a structural and functional diagram.

It was found that the net profit of a trucking company depends on three components: the tariff cost of transportation, the cost of transportation and the amount of taxes.

Formulas for determining the cost of transportation of goods, the cost of transporting goods, conditional and technical costs. In the structure of conditional and technical costs the expenses are considered: on fuel, on lubricants, on tires, on spare parts and materials at performance of maintenance and repair of a rolling stock.

Based on the analysis of the structure of the cost of transportation of goods by car, ten indicators are identified, which determine the «unplanned» costs, such as: costs associated with increasing the distance of transportation of goods; costs associated with damage and loss of cargo; costs associated with additional storage of cargo; costs associated with increasing the cost of preparing the goods for transportation; costs associated with increasing the cost of warehousing.

It was found that conditional fixed costs (depreciation costs, overhead costs, the amount of taxes) do not significantly affect the size of the annual economic effect when updating the rolling stock.

The dependences for determination of: specific conditional and technical expenses for operation of the car at delivery of freights are received; the magnitude of the annual economic effect achieved by the owner of the trucks when updating the rolling stock.

Keywords: truck, criterion, rolling stock, cost, conditional organizational costs, conditional technical costs.

ХАВРУК Володимир Олександрович, асистент кафедри технічної експлуатації автомобілів та автосервісу, Національний транспортний університет, e-mail: khavruk@gmail.com. http://orcid.org/0000-0002-4686-4109.

ПАРХОМЕНКО Олександр Олександрович, асистент кафедри технічної експлуатації автомобілів та автосервісу, Національний транспортний університет, e-mail: olparkhom@gmail.com. http://orcid.org/0000-0002-4752-0148.

Volodymyr KHAVRUK, Assistant of Motor Vehicle Maintenance and Service Department, Kyiv National Transport University, e-mail: khavruk@gmail.com. http://orcid.org/0000-0002-4686-4109.

Oleksandr PARKHOMENKO, Assistant of Motor Vehicle Maintenance and Service Department, Kyiv National Transport University, e-mail: olparkhom@gmail.com. http://orcid.org/0000-0002-4752-0148.

DOI 10.36910/automash.v2i17.646 